\title{
Engineering Education For Generation Z
}

\author{
Kevin Moore, Oklahoma State University Stillwater, USA \\ Carol Jones, Oklahoma State University Stillwater, USA \\ Robert Scott Frazier, Oklahoma State University Stillwater, USA
}

\begin{abstract}
Generation $Z$ is gaining popularity as the name used to refer to those born beginning in the mid to late 1990s. This is the generation that follows the Millennials, and they are just starting to arrive on college campuses. Much attention has been paid to Millennials and their impact on society, and because of this Generation $Z$ members are often lumped together with this older cohort. But Generation Z students are unique, and universities and colleges must prepare to meet the challenges of instructing this new generation. Engineering educators in particular are being challenged to adapt to the speed of technological change. Faculty must consider how to adjust to this new environment, including the changing needs and expectations of Generation $Z$ students. This paper explores these topics. The first section will explore the concept of a generation and describe some of the attributes associated with Generation Z. The second section will review the development of engineering education in the United States and some of the major reforms that have occurred in the past 100 years. The last section will discuss potential changes in the classroom to try and address some of the characteristics of Generation $Z$ students.
\end{abstract}

Keywords: Generation Z; Engineering Education; Undergraduate Education; Generations

\section{WHAT IS A GENERATION?}

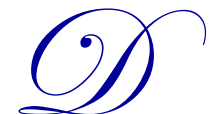

efining a generation is challenging. There is no universally accepted methodology for setting the boundaries between one generation and another. Karl Mannheim is recognized for his early work in utilizing generational differences as a way of understanding social change. Mannheim (1952) argued that generations are bound together by their location in time as well as their socioeconomic class. Shared location in time provides common thoughts and experiences that can overcome other social differences. Eyerman and Turner (1998) sought to establish some theoretical underpinnings for generations. They described generations as a cohort that is shaped by traumatic events such as war, possesses a collective memory, and shares a common way of thinking and culture which binds it together over time. Another definition of a generation is provided by Campbell (2015) as, "[G]roups of individuals born during the same time period who experience a similar cultural context and, in turn, create the culture" (p. 324). The time in which we are born and the events that we experience shape us and our culture, and appear to make a strong bond between members of a generation.

Researchers and writers have used different criteria over the years to set the boundaries of different generations. Time periods assigned to each generation are typically fifteen to twenty years and are shaped by factors such as demographics, historical events, and consensus among researchers (Pew Research Center, 2015). There are considerable variations in the names and dates associated with each generation. Reeves and Oh (2008) compiled a list of generational labels and dates from a variety of sources as shown in Table 1. 
Table 1. Generational Labels and Dates from Different Sources

\begin{tabular}{|c|c|c|c|c|c|}
\hline Source & & & Labels & & \\
\hline $\begin{array}{l}\text { Howe and Strauss } \\
(2000)\end{array}$ & $\begin{array}{l}\text { Silent Generation } \\
(1925-1943 B)\end{array}$ & $\begin{array}{l}\text { Boom Generation } \\
(1943-1960)\end{array}$ & $\begin{array}{l}13^{\text {th }} \text { Generation } \\
(1961-1981)\end{array}$ & $\begin{array}{l}\text { Millennial Generation } \\
(1982-2000)\end{array}$ & - \\
\hline $\begin{array}{l}\text { Lancaster and } \\
\text { Stillman (2002) }\end{array}$ & $\begin{array}{l}\text { Traditionalists } \\
(1900-1945)\end{array}$ & $\begin{array}{l}\text { Baby Boomers } \\
(1946-1964)\end{array}$ & $\begin{array}{l}\text { Generation Xers } \\
(1965-1980)\end{array}$ & $\begin{array}{l}\text { Millennial Generation, Echo } \\
\text { Boomer, Generation Y, Baby } \\
\text { Busters, Generation Next } \\
(1981-1999)\end{array}$ & - \\
\hline $\begin{array}{l}\text { Martin and } \\
\text { Tulgan (2002) }\end{array}$ & $\begin{array}{l}\text { Silent Generation } \\
(1925-1942)\end{array}$ & $\begin{array}{l}\text { Baby Boomers } \\
(1946-1960)\end{array}$ & $\begin{array}{l}\text { Generation X } \\
(1965-1977)\end{array}$ & $\begin{array}{l}\text { Millennials } \\
(1978-2000)\end{array}$ & - \\
\hline $\begin{array}{l}\text { Oblinger and } \\
\text { Oblinger (2005) }\end{array}$ & $\begin{array}{l}\text { Matures } \\
(<1946)\end{array}$ & $\begin{array}{l}\text { Baby Boomers } \\
(1947-1964)\end{array}$ & $\begin{array}{l}\text { Gen_Xers } \\
(1965-1980)\end{array}$ & $\begin{array}{l}\text { Gen-Y, NetGen, Millennials } \\
(1981-1995)\end{array}$ & $\begin{array}{l}\text { Post-Millennials } \\
\text { (1995-present) }\end{array}$ \\
\hline Tapscott (1998) & - & $\begin{array}{l}\text { Baby Boom } \\
\text { Generation } \\
(1946-1964)\end{array}$ & $\begin{array}{l}\text { Generation X } \\
(1965-1975)\end{array}$ & $\begin{array}{l}\text { Digital Generation } \\
(1976-2000)\end{array}$ & - \\
\hline $\begin{array}{l}\text { Zemke et al. } \\
(2000)\end{array}$ & $\begin{array}{l}\text { Veterans } \\
(1922-1943)\end{array}$ & $\begin{array}{l}\text { Baby Boomers } \\
(1943-1960)\end{array}$ & $\begin{array}{l}\text { Gen-Xers } \\
(1960-1980)\end{array}$ & $\begin{array}{l}\text { Nexters } \\
(1980-1999)\end{array}$ & - \\
\hline
\end{tabular}

Source: Reeves and Oh, Generational Differences (2008).

For the purpose of discussion, the classification suggested by the Pew Research Center (2015) will be used. They classify the generations as follows:

\begin{tabular}{c|c|c|c|c|c|}
\hline $\begin{array}{c}\text { Greatest } \\
\text { Generation }\end{array}$ & Silent Generation & $\begin{array}{c}\text { Baby Boom } \\
\text { Generation }\end{array}$ & Generation X & $\begin{array}{c}\text { Millennial } \\
\text { Generation }\end{array}$ & $\begin{array}{c}\text { Post Millennials } \\
\text { (Generation Z) }\end{array}$ \\
\hline before 1928 & $1928-1945$ & $1946-1964$ & $1965-1980$ & $1981-1997$ & $1998-$ present \\
\hline
\end{tabular}

Since members of each generation are impacted by the time and events that they are exposed to, it is useful to consider some of the differences between generations that are currently present in the workforce (Table 2). Baby Boomers, Generation X, and Millennials each make up about one-third of the workforce. Millennials became the largest group in 2015, and the percentage of Boomers continues to decline due to retirement (Fry, 2015).

Table 2. Generational differences.

\begin{tabular}{|c|c|c|c|c|}
\hline & Baby Boomers & Generation X & Millennials & Generation $\mathbf{Z}$ \\
\hline Events & $\begin{array}{l}\text { MLK, JFK, Woodstock, } \\
\text { protests, Vietnam War }\end{array}$ & $\begin{array}{l}\text { Cold War, AIDS, Clinton } \\
\text { scandal, Challenger } \\
\text { explosion, Fall of Berlin } \\
\text { Wall }\end{array}$ & $\begin{array}{l}\text { School shootings, } \\
\text { September 11, Iraq War, } \\
\text { "Great Recession" }\end{array}$ & $\begin{array}{l}\text { Obama presidency, global } \\
\text { terrorism, same-sex } \\
\text { marriage, emergence of } \\
\text { China }\end{array}$ \\
\hline New technology & Television & Computers & Internet & Smart phones \\
\hline View of self & Confident & Independent & Winner & Adaptive \\
\hline Learning / teaching & Rote, hands-on & $\begin{array}{l}\text { Self-directed, mix } \\
\text { traditional with } \\
\text { technology }\end{array}$ & Groups, lots of tests & $\begin{array}{l}\text { Groups, lots of tests, on- } \\
\text { line, "gamification" }\end{array}$ \\
\hline Education & Freedom of expression & Pragmatic & $\begin{array}{l}\text { Structure of } \\
\text { accountability }\end{array}$ & Individualized \\
\hline Trust & Low trust of authority & Low trust of authority & High trust of authority & High trust of authority \\
\hline Career goals & Build a stellar career & Build a portable career & Build parallel careers & $\begin{array}{l}\text { Build a fun, } \\
\text { entrepreneurial career }\end{array}$ \\
\hline Rewards & Title and corner office & Freedom, flexibility & Meaningful work & Social change \\
\hline Parent-child involvement & Receding & $\begin{array}{l}\text { Distant, divorce, latch- } \\
\text { key }\end{array}$ & Intruding (helicopter) & $\begin{array}{l}\text { Connected by technology, } \\
\text { co-pilot }\end{array}$ \\
\hline Family life & Indulged as children & Alienated as children & Protected as children & Connected as children \\
\hline Political orientation & Attack oppression & Apathetic, individual & Crave community & Progressive, equality \\
\hline
\end{tabular}




\subsection{Millennials and Generation $\mathrm{Z}$}

Where to draw the line between Millennials and Generation $\mathrm{Z}$ is still a topic of debate. They have many shared experiences, especially concerning their use of technology. In 2001, Prensky introduced the term "Digital Natives" to describe members of the Millennial generation. He argued that this was the first generation to grow up immersed in computers, smart phones, and the Internet. Some have continued to apply this term broadly to those born in the last thirty years or so. However, Generation $\mathrm{Z}$ members have been especially influenced by immersion in technology since birth. Smart phones, social media, and a "hyperconnected" world has always been a part of life for Generation $\mathrm{Z}$. Because of this, there is a tendency for members of Generation $\mathrm{Z}$ to accept online sources without critical evaluation (Seemiller \& Grace, 2016).

Technological innovations have occurred at a blistering pace during the life of Generation $Z$. The past fifteen years have seen the introduction of the iPod, iPhone, and other smart phones; high speed Internet and WiFi hot spots; Amazon and on-line shopping; social media sites like Facebook and Twitter; YouTube and on-line streaming of television, movies, and games; GPS navigation and self-driving cars. The combination of the Internet, smart phones, and Google allows nearly any question to be answered immediately. The fast pace of innovation has also led to a resurgence in entrepreneurism. Generation $\mathrm{Z}$ students are less concerned about working for a traditional company with an eight to five schedule (Seemiller \& Grace, 2016). And 63\% of Generation Z students believe that college should teach students about starting a business (Northeastern University, 2014).

Millennials and Generation $\mathrm{Z}$ both lived through the financial crash, recession, and slow economic recovery that began in 2007. As a whole the economy performed well as Millennials were growing up, although many were hit hard by the recession as they tried to enter the workforce. Generation $\mathrm{Z}$ has never experienced a booming economy, and this is likely to make them more frugal and conservative when it comes to money. A survey of sixteen to nineteen-year-olds in 2014 found that $60 \%$ were concerned about having enough money, $64 \%$ were concerned about being able to find a job, and $67 \%$ were concerned about being able to afford college (Northeastern University, 2014).

Generation $\mathrm{Z}$ is the first post-9/11 generation. Global terrorism and the war on terror have been in the news consistently during their childhood. $64 \%$ of Generation $\mathrm{Z}$ are concerned about global terrorism. The same percentage are concerned about the U.S. going to war with another country. 59\% are concerned that they will be a victim of a violent crime (Northeastern University, 2014). The world seems like a scary place, although some of this may be related to the twenty-four hour nature of news. Terrorism, mass-shootings, police violence, "superstorms", and global health epidemics like ebola and the Zika virus are just some of the issues that Generation Z have seen on the news. This may help explain why members of Generation $Z$ are not considered to be risk-takers (Seemiller \& Grace, 2016).

In general, members of Generation $\mathrm{Z}$ are thought to be more tolerant than previous generations. They have grown up with the first African-American president and the first female presidential candidate for a major party. They have seen the Supreme Court affirm the right to same-sex marriage. According to Northeastern University, $73 \%$ of those polled believe that it is better for the United States to be a country with many races and languages. Additionally, $73 \%$ support marriage rights regardless of sexual orientation, and $74 \%$ believe in equal rights for transgender people (Northeastern University, 2014).

If the starting point for Generation $\mathrm{Z}$ is placed in the mid to late 1990's, this places them during a time of strong population growth in the United States (Figure 1). The reduction from 2007-2010 is likely associated with the economic downturn experienced during this time (Hamilton et al., 2015). Looking at college attendance, growth is seen as Millennials began to enter college around the year 2000 (Figure 2). This growth can be seen in absolute terms in Figure 3, with a 54\% enrollment increase in colleges and universities (Snyder, 2016). This reflects a growth in population and a larger percentage of eighteen to twenty-four-year-olds seeking postsecondary education. This is likely to continue as Generation Z students begin to arrive at universities in 2016. 
Figure 1. Birth rates in the United States have exhibited a generally upward trend since the mid-1970's.

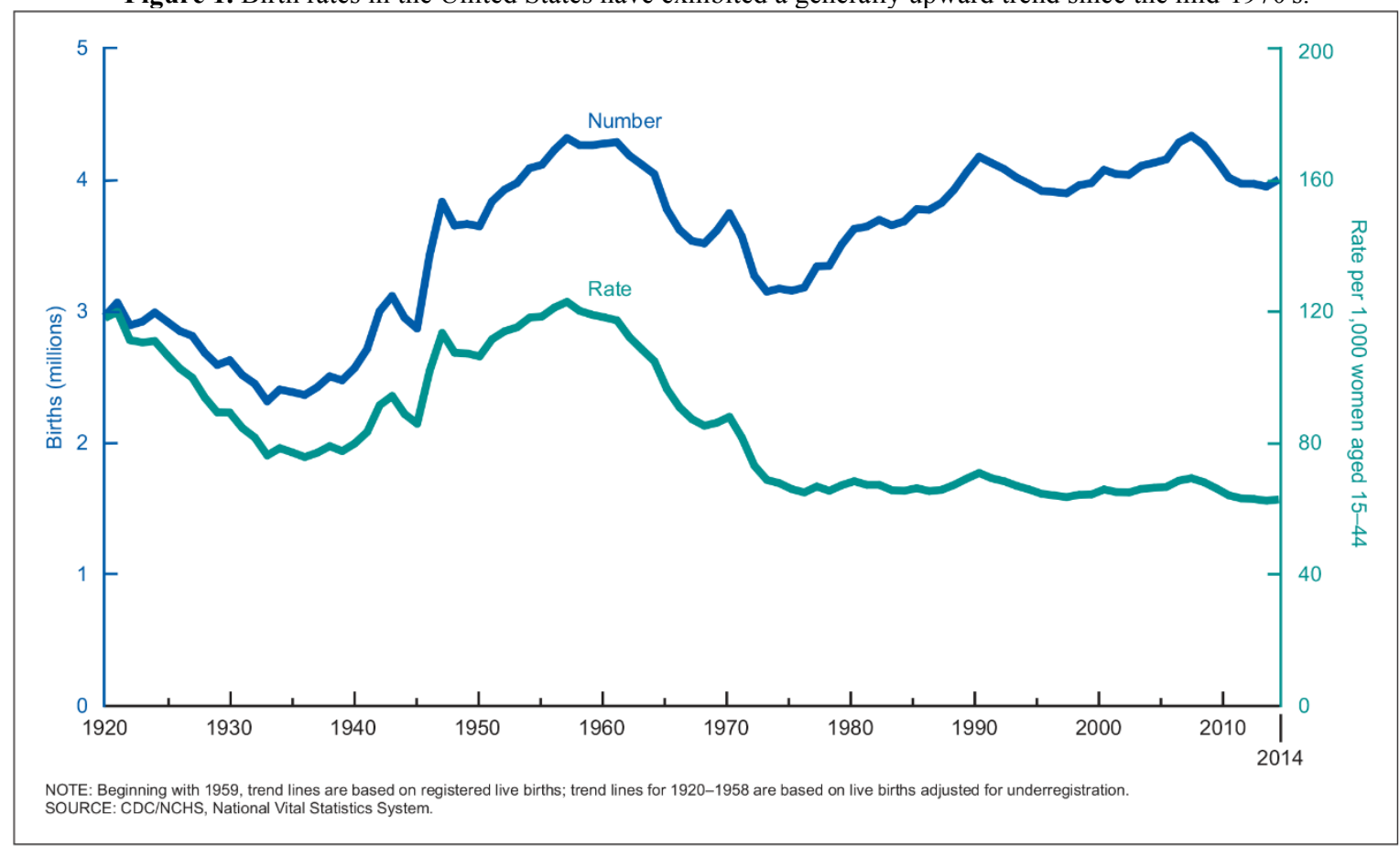

Figure 2. Growth in the percentage of 18-24 year-olds attending colleges and universities increased moderately as Millennial students came of age.

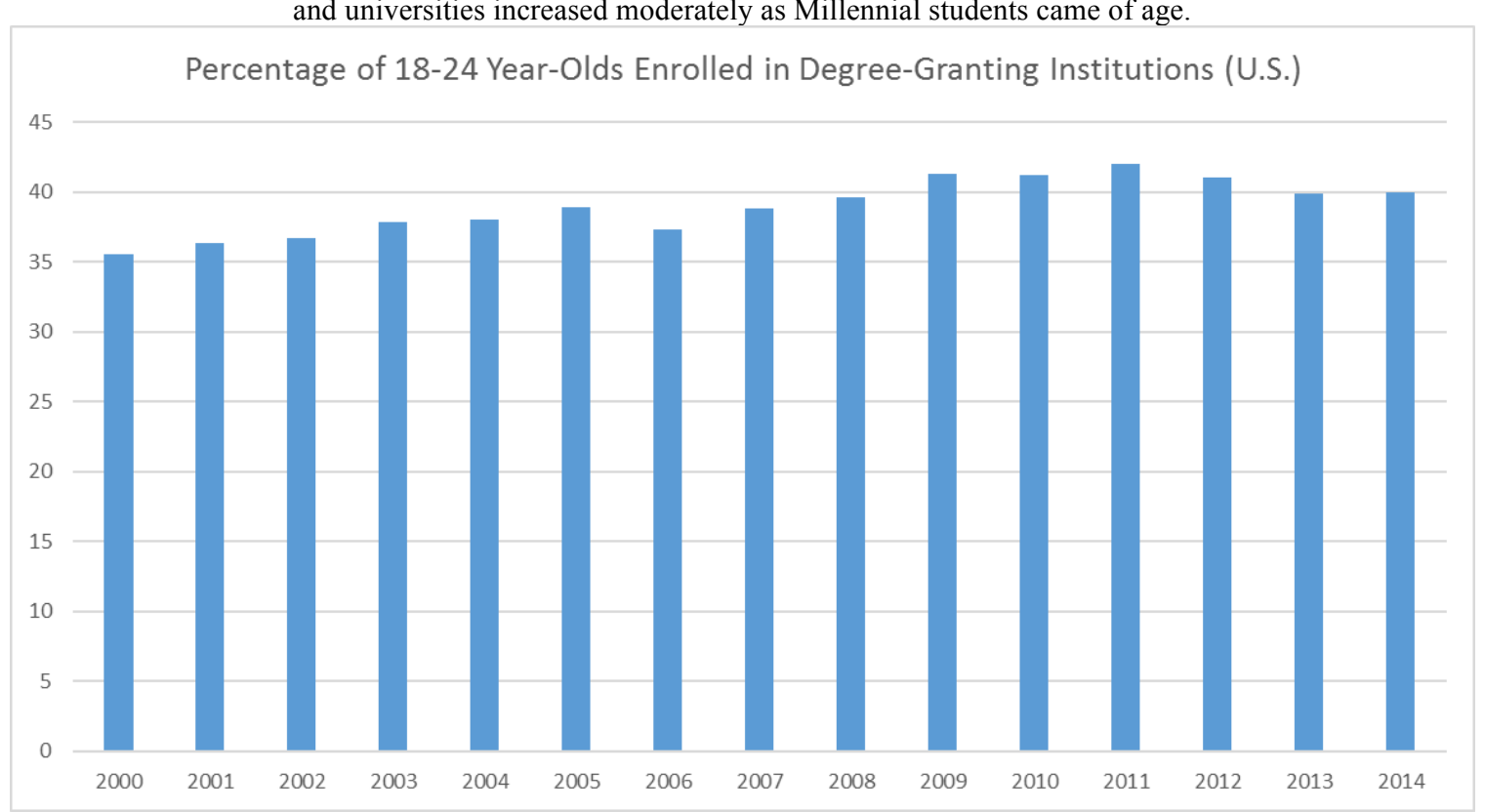


Figure 3. Growth in total enrollment at colleges and universities in the U.S. from 2000-2014.

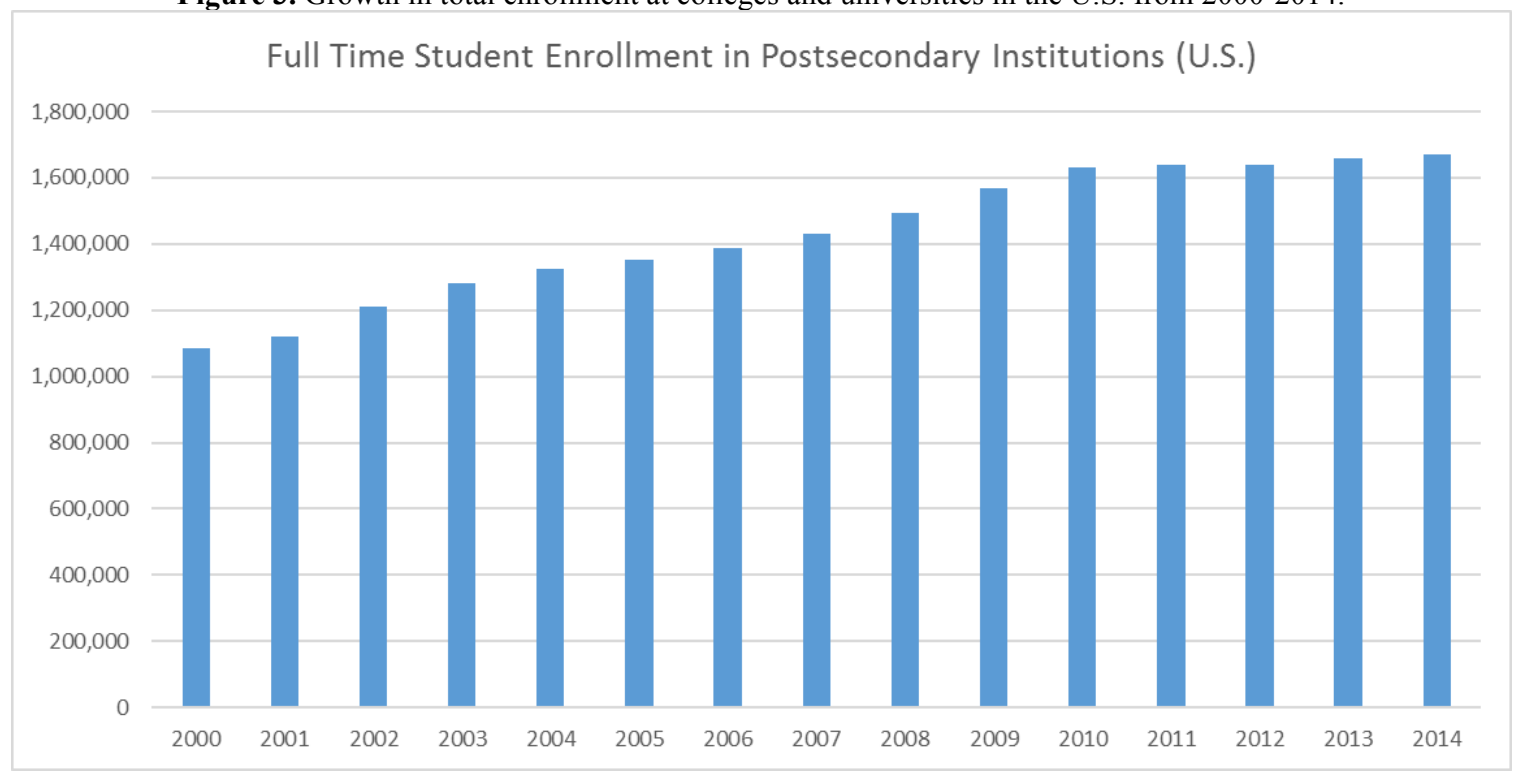

The growth rate in engineering programs has been even stronger during this period (Figure 4), with an increase of $78 \%$ from the year 2000 to 2015 (Gibbons, 2009; Yoder, 2015).

Figure 4. Undergraduate enrollment in engineering has trended upward since 2005.

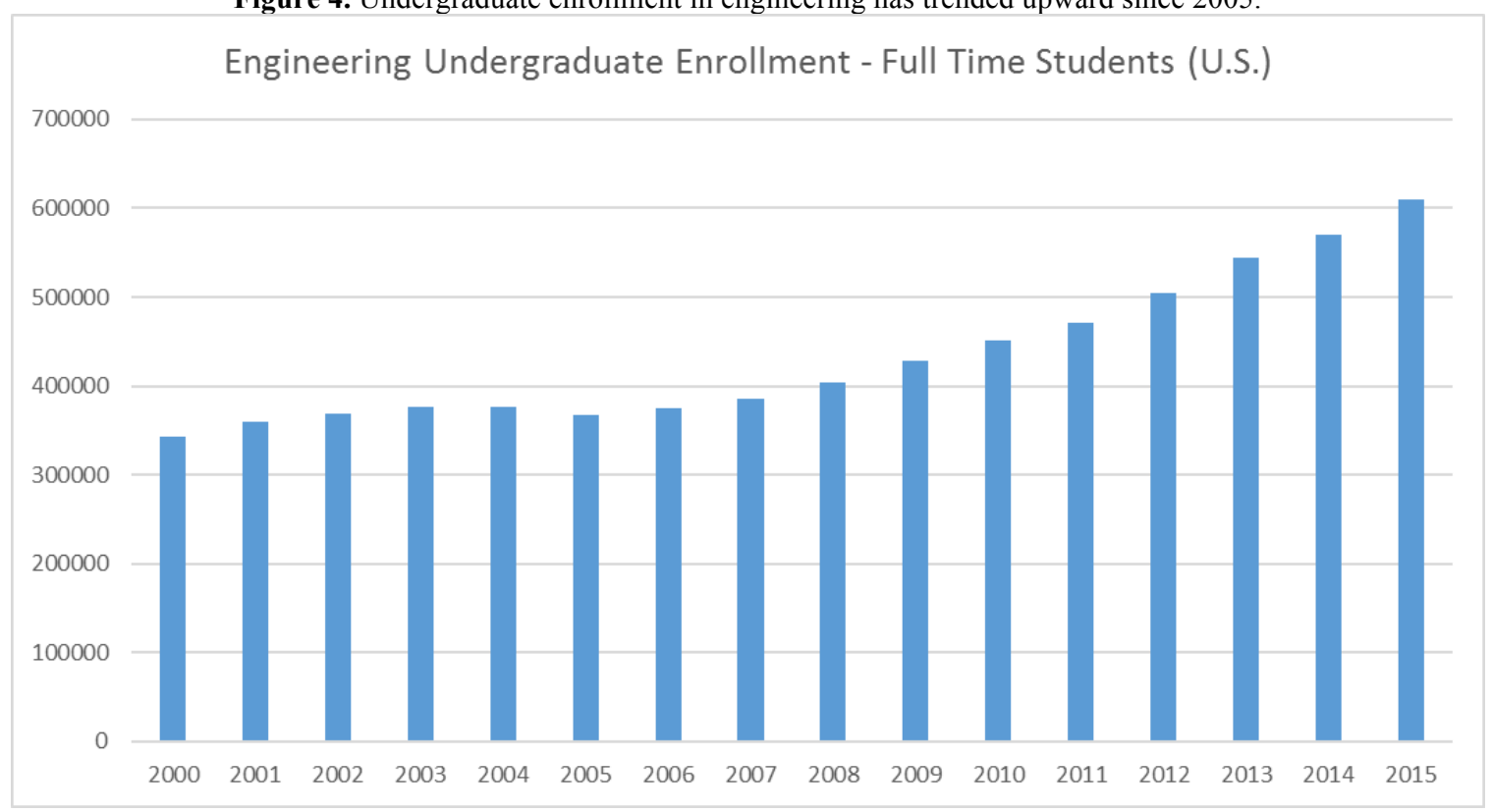

\subsection{Generation Z Learning Styles}

The learning environment of Generation $\mathrm{Z}$ students was shaped by the introduction of the No Child Left Behind Act of 2001. A significant increase in the number of "high-stakes" standardized tests completed by students has led schools to focus on tested subjects and reduce the amount of time spent on untested subjects such as social studies (Jennings \& Rentner, 2006). As a result, students are accustomed to learning to the test and being provided with 
regular assessment and feedback. They may also have less experience with creative-based learning and may need help developing their creativity (Seemiller \& Grace, 2016).

The Internet and widespread use of smart phones has also had a major impact on learning styles. Members of Generation $\mathrm{Z}$ have grown up in a world that is always connected. The answer to any question is just a Google search away. Learning is not limited to the classroom, but can be accessed via YouTube and free learning sites like Khan Academy. According to a study by Seemiller and Grace (2016), Generation Z students like independent, self-paced learning, with opportunities for collaboration as needed. They see their instructor as a learning facilitator, who helps them to develop relevant and practical skills. They may also need help critically evaluating online sources and learning how to process large amounts of information. Somewhat unexpectedly, they prefer face-to-face communication over e-mail or talking on the phone. These attitudes are supported by a study of 1,000 sixteen to nineteen-year-olds completed by Northeastern University (2014). This study found that $72 \%$ of students feel they should be able to design their own college major, $63 \%$ believe it is important to learn about entrepreneurship, and $66 \%$ prefer to interact with friends in person versus social media.

Generation $\mathrm{Z}$ students have access to more resources than ever before, but they need assistance in learning how to process the information. The Pew Research Center completed a survey composed primarily of high school teachers in Advanced Placement and other accelerated courses concerning the impact of the Internet on student's research skills. $76 \%$ of teachers strongly agreed that students are conditioned to expect information will be readily available via search engines. In addition, $83 \%$ strongly agree that students are overwhelmed by the amount of information available on the Internet. This is coupled with $60 \%$ who feel that students are not proficient at assessing the quality of information they find online and $71 \%$ who said their students are not proficient at recognizing bias in online information (Purcell et al., 2012).

The widespread adoption of wireless and smart phone technology has certainly changed the way that we access information and communicate with one another, but Prensky \& Berry (2001) argued that immersion in video games and other technology actually changes the structure of the brain and how younger people think and learn, and that video games should be integrated into learning activities. A study by Thompson (2013) sought to test these claims by surveying a group of university freshmen concerning their technology use and approaches to learning. This study indicates that so-called "Digital Natives" are actually not power users of technology tools. Most reported technology use related to text messaging, social media, general web search, videos and music. The study did indicate a correlation between rapid communication technology such as texting and less productive learning behaviors such as difficultly controlling multitasking, but noted that this may simply be a convenient means of procrastination. In fact, Seemiller and Grace (2016) recommend helping students with scheduling of deliverables on large projects to help avoid "binge homework".

The unique experiences, skills, and expectations of Generation $\mathrm{Z}$ students should be considered as educators develop new and innovative ways to instruct future engineers. Understanding the historical context and current best practices of engineering education will help to inform decisions on working with Generation Z students most effectively.

\section{ENGINEERING EDUCATION - HISTORICAL PERSPECTIVE}

In the early years of the United States, engineering education followed the English system of apprenticeship. An apprentice would work alongside an experienced surveyor, draftsman, or machinist to learn the trade (Seely, 2005). However, the apprenticeship model could not keep pace with the demand for engineers as the United States grew rapidly in the 1800's. Most American universities at this time followed the classical college model of instruction in philosophy, Greek and Latin languages, and classic literature; culminating in a bachelor of arts (B.A.) degree (Reynolds, 1992). But this did not provide the type of education necessary to produce engineers for a growing country. The first engineering program was established by Congress in 1802 at the United States Military Academy at West Point. The goal of this program was to train engineers in both military and civil engineering principles. The educational program was formalized in 1917 by Colonel Sylvanus Taylor on the model of the French Ecole Polytechnique, with a focus on mathematics and science (Grayson, 1977). Early engineering programs struggled at first to establish themselves as a respectable field of study. However, a number of universities began to offer engineering coursework during the first half of the 1800's. Many of these programs did not lead to degrees, but 
rather certificates of completion. Some of these programs were influenced by the English mechanics' institutes or lyceums which provided vocational education to workers. Other schools such as the Universities of Alabama, Georgia, Maryland, Mississippi, Missouri, North Carolina, and Virginia experimented with integrating engineering coursework into the normal B.A. curriculum (Reynolds, 1992).

The Morrill Act of 1862 established the land-grant college system and facilitated the marriage of practical and liberal education. The stated purpose of the Morrill Act was, "to teach such branches of learning as are related to agriculture and the mechanic arts...in order to promote the liberal and practical education of the industrial classes in the several pursuits and professions in life" (Grubb \& Lazerson, 2005, p. 3). In the ten years following the passage of the Morrill Act, the number of engineering school increased from about twelve in 1862 to seventy in 1872 . The first degree in civil engineering was granted by Rensselaer Institute in 1835 . Mechanical engineering and mining engineering programs began in the Polytechnic College of Pennsylvania in 1854 and 1857, respectively. Electrical engineering was introduced in 1882 at the Massachusetts Institute of Technology, and chemical engineering in 1895 at the University of Illinois (Grayson, 1977). During this time the importance of disseminating best practices in engineering education was recognized, and the Society for the Promotion of Engineering Education was formed during the International Congress on Engineering in 1893. This group would lead the way in guiding the formation and reformation of engineering programs across the United States, eventually becoming the American Society for Engineering Education (ASEE) in 1946 (Reynolds \& Seely, 1993).

From the beginning, there were debates concerning what should be included in the engineering curriculum, as well as the proper balance between practical and theoretical education. Several large scale studies were completed during the twentieth and twenty-first century, starting with the Mann report in 1918. Among other recommendations, the Mann report suggested a common curriculum during the first two to three years, with a balance between industrial practice and the study of science and mathematics. This was followed by the Wickenden study, conducted between 1923 and 1929, which looked broadly at everything from student preparation and admission standards to employer attitudes and European educational practices. This study pushed back against calls to increase the length of degree programs from four to five years, called for the introduction of economics and humanities to the curriculum, and set in motion a movement to begin the accreditation of engineering schools. In 1940, the Hammond report, "The Aims and Scope of Engineering Education", was published. This called for the establishment of two "stems" in engineering education; a main stem of science, mathematics, and technology, augmented by a humanities stem to reflect the non-technical work in management that frequently accompanied careers in engineering (Reynolds \& Seely, 1993).

World War II witnessed the development of new technology that pushed the boundaries of physics and chemistry such as radar, aerodynamics, material science, and the atomic bomb. Many of these advances were made by physicists with advanced theoretical training. This brought to light deficiencies in the education of engineers, especially the limited amount of graduate study and research performed by engineering programs (Grayson, 1977). The Grinter report in 1956 recommended more emphasis be placed on mathematics and engineering sciences (mechanics of solids, fluid mechanics, thermodynamics, heat and mass transfer, electrical theory, nature and properties of material) (Froyd et al., 2012). Coupled with this was a large inflow of government sponsored research money for fundamental (versus applied) research during the post-war period. This spurred significant expansion of graduate programs in engineering and began to favor the hiring of faculty with research experience versus industry experience (Seely, 2005). The Goals Report, issued in 1968, suggested that engineering programs utilize a common curriculum during the first four years of instruction, with specialized professional education during a master's degree. The report argued that this was necessary to meet the demands for more science and liberal arts education and matched the requirements for graduate study for other professional degrees such as law and medicine. This report was met with strong opposition but brought to light the challenges present in meeting the broad demands of an engineering degree program (Reynolds \& Seely, 1993). Practicing engineers began to complain of the growing disconnect between university preparation and the skills needed by practicing engineers. Engineering professional societies and the Accreditation Board for Engineering and Technology (ABET) began to push for reforms in engineering education, including the re-emphasis of design in the curriculum and stronger connections between faculty and industry personnel. This led to outcomes-based accreditation and the ABET EC2000 project, which identified eleven competencies needed by graduating engineering students (Criterion 3, a-k) as part of the accreditation process (Seely, 2005). 


\subsection{Recent Efforts to Improve Engineering Education}

As we consider engineering education reform, first we need to determine what skills and qualities we want to produce in engineering graduates. There are some competing values at play, since engineering students can serve in diverse roles after graduation. Anecdotally, about $15-20 \%$ of engineering graduates will continue on to graduate school. The rest will enter the work force, with some staying on a technical track for most of their careers while others become engaged in supervisory or managerial positions. The perceived disconnect between student preparation and the skills needed in the workplace led to a major change in the engineering accreditation criteria in the mid-1990's. One of the companies involved in leading this charge to better align education and practice was The Boeing Company. They outlined the following attributes desired in an engineering graduate (Crawley et al., 2007):

- A good understanding of engineering science fundamentals

- A good understanding of design and manufacturing processes

- A multi-disciplinary systems perspective

- A basic understanding of the context in which engineering is practiced

- Good communication skills

- High ethical standards

- An ability to think both critically and creatively—independently and cooperatively

- Flexibility, i.e., the ability and self-confidence to adapt to rapid or major change

- Curiosity and a desire to learn for life

- A profound understanding of the importance of teamwork.

In 1995, ABET introduced Engineering Criteria 2000 (EC2000). This was a complete makeover of engineering accreditation in the US, with a focus on student outcomes and competencies (Froyd et al., 2012). ABET outcomes (a) through (k) (Table 2) are a good starting point when discussing the desired attributes of an engineering graduate (Engineering Accreditation Commission, 2016). These outcomes cover technical knowledge as well as "soft skills" such as communication and working in teams.

Table 3. ABET Criterion 3, Outcomes (a) - (k)

a) an ability to apply knowledge of mathematics, science, and engineering

b) an ability to design and conduct experiments, as well as to analyze and interpret data

c) an ability to design a system, component, or process to meet desired needs within realistic constraints such as economic, environmental, social, political, ethical, health and safety, manufacturability, and sustainability

d) an ability to function on multidisciplinary teams

e) an ability to identify, formulate, and solve engineering problems

f) an understanding of professional and ethical responsibility

g) an ability to communicate effectively

h) the broad education necessary to understand the impact of engineering solutions in a global, economic, environmental, and societal context

i) a recognition of the need for, and an ability to engage in life-long learning

j) a knowledge of contemporary issues

k) an ability to use the techniques, skills, and modern engineering tools necessary for engineering practice.

Another effort to define the desired attributes of engineering graduates was completed by the National Academy of Engineering. It focused on the skills engineers would need to solve the challenges of 2020 and beyond (Clough, 2004).

1. Strong analytical skills

2. Practical ingenuity

3. Creativity

4. Good communication skills

5. Understand the principles of business, management, and leadership

6. High ethical standards and professionalism 


\section{Adaptable to change}

8. Lifelong learners

The outcomes based assessment introduced for accreditation by EC2000 led to changes in engineering instruction. One method of reform has been to introduce active learning and problem (or project) based learning (PBL). Active learning breaks from the traditional lecture-based teaching model by integrating activities into the lecture such as reflective writing, briefly discussing lecture questions among a small group of students, working problems in class, etc. Problem based learning uses a complex, multidisciplinary problem as an overarching scaffold for learning throughout the course. Learning objectives and lectures throughout the class are focused on developing the knowledge and skills required to solve the problem. PBL has been shown to enhance learning while improving students' ability to work collaboratively, solve complex problems, and learn independently (Slavich \& Zimbardo, 2012). Similarly, courses that incorporate active learning techniques have been shown to increase examination performance and reduce failure rates in STEM courses versus traditional lecture alone (Freeman et al., 2014). A common example of PBL in engineering curriculum is the capstone or senior design class. Introduction of these classes began in the 1960's and a half year of design became a requirement of ABET accreditation in the 1970's. This was supposed to include at least one design class that integrated material from across the curriculum (Froyd et al., 2012). Freshman engineering design classes have also become common in engineering programs and typically utilize active and problem based learning techniques. These classes became popular in the 1990's as a means of exposing students to engineering topics (and faculty members) during a time in the curriculum that is mainly devoted to foundational topics in mathematics and science (Dym et al., 2005). Some efforts have been made to link freshman and capstone design projects together to improve learning and help freshman engage in real-world design projects (Fox et al., 2015). Rowan University stands out as a model for integration of design projects throughout the curriculum, with multidisciplinary "design clinics" present in every semester of the undergraduate curriculum (Sukumaran et al., 2006).

A large scale effort to reimagine engineering education started at the Massachusetts Institute of Technology (MIT) in the 1990's under the guidance of Charles M. Vest. Dr. Vest served as university president of MIT for fourteen years and then the president of the National Academy of Engineering for seven years. The goal of the project was to develop graduates who were "ready to engineer", possessing both technical fundamentals and pre-professional engineering skills. Initial collaborators on the project included three Swedish universities; Chalmers University of Technology, the Royal Institute of Technology, and Linköping University. The system they developed is called the CDIO approach - focused on teaching students to, "Conceive-Design-Implement-Operate complex value-added engineering products, processes, and systems in a modern, team-based environment." Currently over 100 universities are using the CDIO approach (Crawley et al., 2007). The main struggle CDIO tries to address is teaching engineering technical fundamentals while simultaneously teaching professional practice. CDIO uses active learning and project based learning techniques, using Conceive-Design-Implement-Operate as the contextual backbone for all of the classes. This system requires a commitment of faculty and administration to completely revamp the curriculum in an effort to improve student educational outcomes.

\section{RECOMMENDATIONS FOR WORKING WITH GENERATION Z}

Generation Z students will certainly come to the university with different experiences and skill sets than the Generation $X$ and Baby Boomer instructors teaching the majority of their classes. New educational techniques will seek to address these differences but they will also simply be grounded in good pedagogy. There are five areas in particular that deserve attention and can be integrated into the classroom without a complete revamp of the curriculum. Future research will seek to test some of these hypotheses, and potential research questions are included at the end of each section.

\subsection{Integrate Active and Problem Based Learning}

Active and problem based learning has been shown to improve performance in STEM classes and to develop skills in solving complex problems (Freeman et al., 2014; Slavich \& Zimbardo, 2012). These are key factors in developing successful engineers. Additionally, these techniques are likely to assist in developing creativity and student engagement. PBL techniques are already well established in senior design classes. We recommend integrating them 
throughout the curriculum. This has been executed successfully at places such as Rowan University, Olin College, and universities participating in the CDIO initiative (Crawley et al., 2005; Edström \& Kolmos, 2014; Kadlowec et al., 2007; Somerville et al., 2005).

There are many opportunities for integrating current technology into project based classes. While Generation Z students have grown up immersed in technology they do not necessarily understand how it works. Investigating everyday items such as touch screens, electric motors, and motion detectors can provide an accessible starting point for class projects. More complicated projects that require additional time to understand and quantify could also be beneficial. By providing projects that cannot be solved with a Google search, instructors can lead students through the process of understanding and describing a problem and its boundaries, developing and testing potential solutions, and delivering a final product that is well defined and meets the overall needs of the client. Clearly this type of teaching requires engaged instructors and additional classroom time. The use of on-line learning to augment classroom instruction is one method of providing additional class time for active learning. This is often referred to as a "flipped classroom", where some of the normal lecture content is pre-recorded and watched by students outside of class (Tucker, 2012). This also connects to Generation Z's desire for more independent, self-paced study. But quality expectations are high - Generation $Z$ students have been streaming online content since they could hold a smart phone. Some universities have recording equipment or even small studios that can vastly improve the quality of recorded lectures. There are also online resources available through sites such as MIT OpenCourseWare, Khan Academy, and YouTube that may be useful.

Research questions: 1) Do students retain more information using project based learning techniques? 2) Does faculty led discussion of problem analysis and evaluation improve problem solving techniques in students? 3) Is there a practical size limit for a flipped classroom? How is this impacted by the design of the room/furniture?

\subsection{Help Students Extract Answers from an Ocean of Information}

Generation $\mathrm{Z}$ students are faced with an overwhelming amount of information on the Internet, and they are often poorly equipped to find good answers to challenging questions. A Pew Research Center survey of teachers primarily in advanced high school courses found that $78 \%$ of teachers rated their students as fair or poor in looking for information that is hard to find (Purcell et al., 2012). This is an important skill for engineers to possess, so faculty must help students to learn to use research tools like the Internet effectively. Since students are accustomed to turning to search engines for quick answers, rote memorization of facts or equations will not be seen as important. However, teaching them to find and critically evaluate sources of information will be crucial throughout their careers. This might begin with a few examples of false or misleading information found on-line. Have students try to identify the quality of the source and clues of potential bias by the author. Discuss the process of peer review and resources such as Google Scholar and library databases. This would be an appropriate time to collaborate with one of the university librarians as well. The importance of engineering standards (ASTM, ASME, ASCE, etc.) and how to find them should also be a topic of discussion. These topics should be introduced early and developed throughout the curriculum. The rapid changes in technology that will occur during the lifetime of engineering graduates mean that this will be one of the most important skills that we can develop in our students.

We also need to teach students to integrate information to form solutions to complex problems. Extensive research with chemical engineering students at McMaster University has shown that traditional lecture activities that are expected to develop problem solving skills are not effective. Students developed the ability to solve problems they had seen previously, but they did not develop general problem solving skills. This finding was confirmed by researchers in other countries and with a variety of technical and non-technical majors (Woods et al., 1997). Out of this research developed a program for teaching problem solving skills, the McMaster Problem Solving Strategy. The six steps in this strategy are: engage, define the stated problem, explore, plan, do it, and look back (Woods, 2000). There are other problem solving approaches as well. The point is that a problem solving strategy needs to be adopted, taught to students, and reinforced throughout the curriculum.

Research questions: 1) Are on-line research techniques being taught in K-12 that can be expanded upon for university students? How does access to the Internet impact the use of problem solving strategies? 


\subsection{Assess Often and Provide Feedback}

Generation $\mathrm{Z}$ students have grown up taking lots of standardized tests. A study of sixty-eight large, urban school districts found that during the 2014-15 school year an average student took about eight standardized tests per year. For eighth-grade students this amounted to approximately $2.3 \%$ of school time (Hart et al., 2015). There has been considerable research on the topic of feedback and assessment. Beginning in the 1990's the focus began moving to a learner-centered, outcomes-oriented model (Hattie \& Jaeger, 1998). This type of thinking likely influenced the move to outcome-based assessment by ABET with EC2000.

Instructors should consider evaluating the effectiveness of their current assessment and feedback models. Feedback should be ongoing and integral to assessment. Students should be engaged in the feedback process, both through peer assessment and by having some input concerning the means and frequency of assessment (Evans, 2013). Hattie and Timperley (2007) state that feedback should address three questions: 1) what are the goals, 2) what progress am I making towards the goals, and 3) what do I need to do to make better progress? They also outline four levels of feedback:

1) praise (e.g. good job)

2) corrective (e.g. indicating right or wrong answers)

3) process oriented (e.g. developing the student's strategies for error detection)

4) focused on self-regulation, engagement, and confidence (e.g. helping students to develop selfmanagement and self-appraisal techniques).

The first level is the least effective. The second level is very common, especially in STEM coursework. Written comments that help student to move to level three or four are the most beneficial, and are most effective when addressing a faulty interpretation. The third and fourth levels are the most effective, and help to develop selfregulation skills that students can apply throughout their careers. Doing this effectively will require the clear communication of learning goals and might also include more frequent, smaller assignments and tests. Feedback should be supplied as soon as possible without losing quality and ideally there will be an opportunity for students to revisit the work based on the feedback provided. When possible, this should also include more frequent meetings with students during group projects.

Research questions: 1) How can feedback for traditional engineering assignments be moved from level two (right or wrong) to higher levels of feedback without overwhelming the instructor? 2) How would engineering students respond to assessment methods outside the normal homework and three exams model? 3) How is the retention of engineering science course material impacted by alternative methods of assessment?

\subsection{Engage Creativity}

According to Felder (1988), engineering education usually deals with problems that have a single solution. However, developing engineers that can solve the big problems of our time requires that we, "...provide our students with opportunities to exercise and augment their natural creative abilities and ... create classroom environments that make these exercises effective" (p. 120). Generation Z students are considered to be risk-adverse (Seemiller \& Grace, 2016). We need to help them to exercise creativity by recognizing (even encouraging) failure as a part of the design process. Felder (1988) encourages the use of open-ended and divergent problems to help foster creativity and help students to realize that most problems are underspecified and do not have a single solution.

Many Generation Z students have an entrepreneurial streak, and this provides another opportunity for project based learning in the context of a real or imagined product development or business start-up. The introduction of entrepreneurship into engineering education is not new. A 2010 study identified forty-seven engineering programs that included entrepreneurship at the undergraduate level. This does not include the numerous university-level initiatives in entrepreneurship (Shartrand et al., 2010). Participation in entrepreneurial activities may even improve student performance and retention. A short-term longitudinal study at North Carolina State University measured a significant difference in GPA (3.08 vs. 2.83 ) and retention in engineering ( $70 \%$ vs. $51 \%$ ) for participants in their Engineering Entrepreneurship Program versus a matched group of non-participants (Ohland et al., 2004). 
Research questions: 1) Do activities and coursework focused on creativity and entrepreneurship in engineering improve the performance of Generation $\mathrm{Z}$ students? If there is a benefit to these activities, what level of participation is required to obtain a significant benefit? What are best practices concerning the integration of creativity into engineering coursework?

\subsection{Help Students Make Connections}

Generation $\mathrm{Z}$ students have unprecedented access to information, but they need help forming a meaningful framework to understand and process this information. Constructivism is a theory of learning based on the notion that learning is a process of connecting new information about the world to an existing framework of knowledge. This theory serves as the basis for experiential learning as well as the CDIO approach to engineering curriculum reform (Crawley et al., 2007). One advantage of the CDIO approach is that it provides a framework or context for students to use as they learn throughout the curriculum. This approach of providing a context for learning can also be applied with the use of concept maps. A concept map is simply a visual learning framework provided by the instructor (and perhaps modified by students) to help students to understand how the "big picture" concepts fit together for a learning objective. Ellis et al. (2004) investigated the use of concept maps (Figure 5) in a sophomore level engineering mechanics course with the goal of helping students to make stronger connections between material in the class as well as prerequisite coursework. The approach was well received by the students and student confidence improved greatly over the course of the semester. A survey question related to, "confidence in skills, abilities, and knowledge in engineering" increased from $11 \%$ at the beginning of the semester to $81 \%$ at the end of the semester.

Figure 5. A concept map of concept maps.

There are hierarchical elements as well as crosslinks to help visualize how concepts are related.

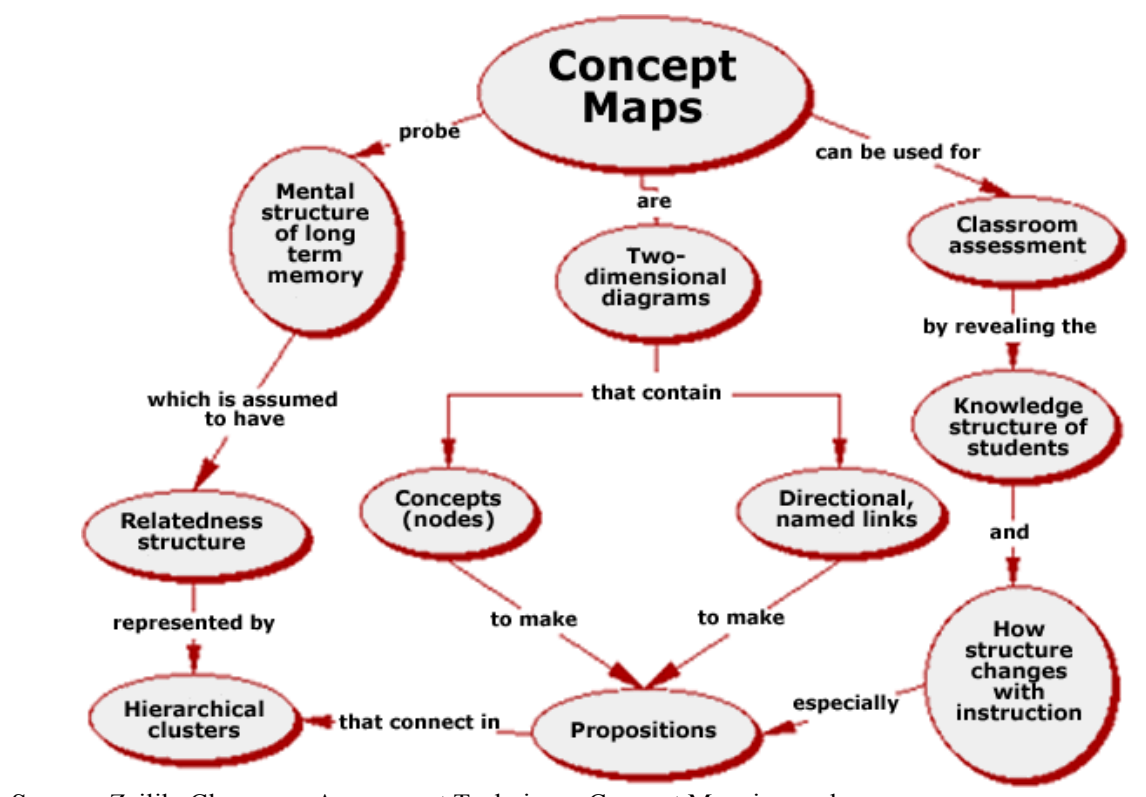

Source: Zeilik, Classroom Assessment Techniques Concept Mapping, n.d.

Applying these concepts broadly to engineering coursework and the overall degree program would be beneficial for Generation $\mathrm{Z}$ students. Students will benefit from an improved understanding of how courses in the curriculum fit together and build on one another. Ideally, this will improve problem solving skills. Especially concerning the solution of novel problems that are typically faced in engineering practice.

Research questions: 1) Is the retention of information between prerequisite classes improved when concept maps or frameworks are integrated into the presentation of course material? 2) Does the introduction and consistent 
reinforcement of a curriculum-wide framework improve the performance and retention of engineering students? 3) Do students who participate in courses with concept maps perform better in solving open-ended or novel problems than those using traditional instruction methods?

\section{AUTHOR BIOGRAPHIES}

Dr. Moore is a Teaching Associate in Engineering Technology at Oklahoma State University (OSU). He worked for eight years as an Applications Engineer at Sulzer Chemtech in Tulsa, OK before returning to OSU as Manager of Proposal Services for the College of Engineering, Architecture, and Technology. He later became the Director of Student Academic Services, leading the recruiting, academic advising, and career services activities of the college for six years. His research topics include post-harvest grain storage, agricultural safety, and electronic sensing of grain quality. Email: kevin.moore@okstate.edu (corresponding author).

Dr. Jones is faculty member of the Biosystems and Agricultural Engineering School at Oklahoma State University. Her research and extension programs include the storage and handling of agricultural products, electromagnetic sensing, agricultural safety and rescue techniques, and integrated pest management. The connection between grain condition and safety is a strong motivation for the equipment research and training she provides. She has lectured in 10 different countries including the Middle East, China, Europe, and South America. New and unique force modeling techniques are a current research focus and will lead to new safety equipment and methods for determining storage structure viability. Email: jcarol@okstate.edu.

Dr. Frazier is faculty member of the Biosystems and Agricultural Engineering School at Oklahoma State University. His specialty areas are energy management, renewable energy systems and life cycle analysis. His research areas include irrigation energy/water nexus, bio-material energy, and waste heat recovery. Dr. Frazier was the assistant director of the Oklahoma State University Industrial Assessment Center from 2003-2006. Dr. Frazier has worked in the energy field for 20 years and during that time has conducted over 400 commercial and industrial energy audits. He has also worked in the electric utility industry on the East Coast. Email: robert.frazier@okstate.edu.

\section{REFERENCES}

Campbell, W. K., Campbell, S. M., Siedor, L. E., \& Twenge, J. M. (2015). Generational Differences Are Real and Useful. Industrial and Organizational Psychology, 8(03), 324-331.

Clough, G. W. (2004). The engineer of 2020: Visions of engineering in the new century. National Academy of Engineering, Washington, $D C$.

Crawley, E., Malmqvist, J., Ostlund, S., \& Brodeur, D. (2007). Rethinking engineering education. The CDIO Approach, 302.

DeBard, R. (2004). Millennials coming to college. New directions for student services, 2004(106), 33-45.

Dym, C. L., Agogino, A. M., Eris, O., Frey, D. D., \& Leifer, L. J. (2005). Engineering design thinking, teaching, and learning. Journal of Engineering Education, 94(1), 103-120.

Edström, K., \& Kolmos, A. (2014). PBL and CDIO: complementary models for engineering education development. European Journal of Engineering Education, 39(5), 539-555.

Ellis, G. W., Rudnitsky, A., \& Silverstein, B. (2004). Using concept maps to enhance understanding in engineering education. International Journal of Engineering Education, 20(6), 1012-1021.

Engineering Accreditation Commission. (2016). Criteria for accrediting engineering programs, 2016-2017. Baltimore, MD. Evans, C. (2013). Making sense of assessment feedback in higher education. Review of educational research, 83(1), 70-120.

Eyerman, R., \& Turner, B. S. (1998). Outline of a theory of generations. European Journal of Social Theory, 1(1), 91-106.

Felder, R. M. (1988). Creativity in engineering education. Chemical Engineering Education, 22(3), 120-125.

Fox, G. A., Weckler, P., \& Thomas, D. (2015). Linking First-Year and Senior Engineering Design Teams: Engaging Early Academic Career Students in Engineering Design. Advances in Engineering Education, 4(3).

Freeman, S., Eddy, S. L., McDonough, M., Smith, M. K., Okoroafor, N., Jordt, H., \& Wenderoth, M. P. (2014). Active learning increases student performance in science, engineering, and mathematics. Proceedings of the National Academy of Sciences, 111(23), 8410-8415.

Froyd, J. E., Wankat, P. C., \& Smith, K. A. (2012). Five major shifts in 100 years of engineering education. Proceedings of the IEEE, 100(Special Centennial Issue), 1344-1360. 
Fry, R. (2015). Millennials Surpass Gen Xers as the Largest Generation in U.S. Labor Force. Pew Research Center. $\mathrm{http}: / / w w w . p e w r e s e a r c h . o r g / f a c t-t a n k / 2015 / 05 / 11 /$ millennials-surpass-gen-xers-as-the-largest-generation-in-u-s-laborforce/

Gibbons, M. T. (2009). Engineering by the Numbers. https://www.asee.org/papers-and-publications/publications/collegeprofiles/09EngineeringbytheNumbersPart1.pdf

Grayson, L. P. (1977). A Brief History of Engineering Education in the United States. Engineering Education, 68(3), $246-264$.

Grubb, W. N., \& Lazerson, M. (2005). Vocationalism in higher education: The triumph of the education gospel. The Journal of Higher Education, 76(1), 1-25.

Hamilton, B.; Martin, J.; Osterman, J.; Curtin, S.; Mathews, T. (2015). Births: Final Data for 2014 Hyattsville, MD: National Center for Health Statistics Retrieved from http://www.cdc.gov/nchs/data/nvsr/nvsr64/nvsr64_12.pdf.

Hart, R., Casserly, M., Uzzell, R., Palacios, M., Corcoran, A., \& Spurgeon, L. (2015). Student testing in America's great city schools: An inventory and preliminary analysis: Council of the Great City Schools.

Hattie, J., \& Jaeger, R. (1998). Assessment and classroom learning: A deductive approach. Assessment in Education: principles, policy \& practice, $5(1), 111-122$.

Hattie, J., \& Timperley, H. (2007). The power of feedback. Review of educational research, 77(1), 81-112.

Jennings, J., \& Rentner, D. S. (2006). Ten big effects of the No Child Left Behind Act on public schools. Phi Delta Kappan, $88(2), 110$.

Kadlowec, J., Bhatia, K., Chandrupatla, T. R., Chen, J. C., Constans, E., Hartman, H., . . Zhang, H. (2007). Design integrated in the mechanical engineering curriculum: Assessment of the engineering clinics. Journal of Mechanical Design, 129(7), 682-691.

Lancaster, L. C., \& Stillman, D. (2002). When generations collide: Who they are. Why they clash. How to solve the generational puzzle at work. New York City: HarperCollins Publishers.

Mannheim, K. (1952). The Problem of Generations. In P. Kecskemeti (Ed.), Essays of the Sociology of Knowledge: Collected Works (Vol. 5, pp. 276-322). New York: Routledge.

Northeastern University. (2014). Meet Generation Z. http://www.northeastern.edu/innovationsurvey/generation-z/index.html\#

Ohland, M. W., Frillman, S. A., Zhang, G., Brawner, C. E., \& Miller, T. K. (2004). The effect of an entrepreneurship program on GPA and retention. Journal of Engineering Education, 93(4), 293-301.

Pew Research Center. (2015). The Whys and Hows of Generations Research. http://www.people-press.org/files/2015/09/09-32015-Generations-explainer-release.pdf

Prensky, M. (2001). Digital natives, digital immigrants part 1. On the horizon, 9(5), 1-6.

Prensky, M., \& Berry, B. D. (2001). Do they really think differently? On the Horizon, 9(6), 1-9.

Purcell, K., Rainie, L., Heaps, A., Buchanan, J., Friedrich, L., Jacklin, A., . . Zickuhr, K. (2012). How Teens Do Research in the Digital World. Pew Internet \& American Life Project.

Reeves, T. C., \& Oh, E. (2008). Generational differences. Handbook of research on educational communications and technology, 3, 295-303.

Reynolds, T. S. (1992). The education of engineers in America before the Morrill Act of 1862. History of Education Quarterly, $32(4), 459-482$.

Reynolds, T. S., \& Seely, B. E. (1993). Striving for balance: A hundred years of the American Society for Engineering Education. Journal of Engineering Education, 82(3), 136-151.

Schuck, S., Aubusson, P., Buchanan, J., \& Russell, T. (2012). The Kids Today: Alphabet Generations in Transition Beginning Teaching (pp. 27-38): Springer.

Seely, B. E. (2005). Patterns in the history of engineering education reform: A brief essay. Educating the engineer of 2020: Adapting engineering education to the new century, 114-130.

Seemiller, C., \& Grace, M. (2016). Generation Z Goes to College: John Wiley \& Sons.

Shartrand, A., Weilerstein, P., \& Besterfield-Sacre, M. (2010). Technology entrepreneurship programs in US engineering schools: An analysis of programs at the undergraduate level (AC 2010-666). Paper presented at the 2010 Annual Conference and Exposition of the American Society for Engineering Education (ASEE), Louisville KY.

Slavich, G. M., \& Zimbardo, P. G. (2012). Transformational teaching: Theoretical underpinnings, basic principles, and core methods. Educational Psychology Review, 24(4), 569-608.

Snyder, T. D. (2016). Digest of Education Statistics: 2014. Washington, DC: Retrieved from http://nces.ed.gov/programs/digest/d14/index.asp.

Somerville, M., Anderson, D., Berbeco, H., Bourne, J. R., Crisman, J., Dabby, D., . . Kerns, D. V. (2005). The Olin curriculum: Thinking toward the future. IEEE Transactions on Education, 48(1), 198-205.

Sukumaran, B., Jahan, K., Dorland, D., Everett, J., Kadlowec, J., Gephardt, Z., \& Chin, S. (2006). Engineering Clinics: An integration of research into the undergraduate engineering curriculum. CUR quarterly, 26(3), 115-121.

Thompson, P. (2013). The digital natives as learners: Technology use patterns and approaches to learning. Computers $\&$ Education, 65, 12-33.

Tucker, B. (2012). The flipped classroom. Education next, 12(1).

Woods, D. R. (2000). An evidence-based strategy for problem solving. Journal of Engineering Education, 89(4), 443. 
Woods, D. R., Hrymak, A. N., Marshall, R. R., Wood, P. E., Crowe, C. M., Hoffman, T. W., . . Bouchard, C. G. (1997). Developing problem solving skills: The McMaster problem solving program. Journal of Engineering Education, 86(2), $75-91$.

Yoder, B. L. (2015). Engineering by the Numbers. https://www.asee.org/papers-and-publications/publications/collegeprofiles/15EngineeringbytheNumbersPart1.pdf

Zeilik, M. (n.d.). Classroom Assessment Techniques Concept Mapping. Retrieved 12/1/2016, from http://www.flaguide.org/cat/conmap/conmap7.php 


\section{NOTES}

